\title{
PROFIL KEMAMPUAN BERPIKIR KRITIS SISWA SMP DALAM MEMECAHKAN MASALAH MATEMATIKA DENGAN INFORMASI YANG KONTRADIKSI BERDASARKAN GENDER
}

\author{
${ }^{1}$ Febrina Ridha Amalia, ${ }^{2}$ Sanusi dan ${ }^{3}$ Swasti Maharani \\ 1,2,3 Program Studi Pendidikan Matematika, Universitas PGRI Madiun \\ Jalan Setiabudi No.85, Madiun \\ Email : fefebrina14@gmail.com
}

\begin{abstract}
Abstrak
Kemampuan berpikir kritis merupakan salah satu komponen yang penting untuk siswa dalam pembelajaran matematika. Hal ini disebabkan karena dengan menggunakan konsep berpikir kritis secara tepat dapat mengarahkan siswa dalam berpikir serta mempermudah siswa untuk memecahkan masalah matematika. Tujuan dari penelitian ini adalah untuk mengetahui kemampuan berpikir kritis siswa Sekolah Menengah Pertama (SMP) dalam memecahkan masalah matematika dengan informasi yang kontradiksi berdasarkan gender. Jenis penelitian ini adalah penelitian deskriptif kualitatif. Teknik analisis data terdiri dari tiga komponen, yaitu reduksi data, penyajian data dan penarikan kesimpulan. Penelitian dilakukan pada siswa kelas VIII SMP Negeri 2 Kauman, Ponorogo. Subjek penelitian ini terdiri dari 2 siswa yaitu siswa laki-laki dan siswa perempuan. Teknik pengumpulan data terdiri dari tes, wawancara dan dokumentasi. Hasil penelitian menunjukkan bahwa siswa laki-laki mampu menerapkan tahap analisis dan tahap evaluasi. Hasil tes tulis pada tahap interpretasi subjek tidak menuliskan yang diketahui maupun yang ditanyakan pada soal. Sedangkan tahap inferensi subjek tidak menuliskan kesimpulan dari penyelesaian soal. Siswa perempuan mampu menerapkan tahap interpretasi, tahap analisis, tahap evaluasi dan tahap inferensi. Penelitian ini dapat dijadikan rekomendasi untuk penelitian selanjutnya yang berkaitan dengan profil kemampuan berpikir kritis siswa SMP dalam memecahkan masalah matematika dengan informasi yang kontradiksi berdasarkan gender dengan menggunakan latar belakang siswa yang lainnya misalkan ditinjau berdasarkan kemampuan kognitif atau afektif.
\end{abstract}

Kata kunci : Kemampuan Berpikir Kritis, Memecahkan Masalah, Informasi yang Kontradiksi, Gender

\section{PENDAHULUAN}

Pendidikan merupakan suatu usaha memperoleh pengetahuan untuk mengembangkan potensi yang ada pada diri seseorang. Pendidikan dapat diperoleh melalui pendidikan formal maupun non formal. Pendidikan mempunyai kedudukan penting dalam menciptakan generasi yang berkualitas agar tidak tertinggal dengan negara lain. Melalui pendidikan dapat dijadikan bekal seseorang untuk memperoleh kehidupan yang lebih baik. Tanpa pendidikan sulit bagi seseorang untuk mewujudkan apa yang diinginkan. Pencapaian 
tujuan nasional Bangsa Indonesia dapat diwujudkan melalui pendidikan. Oleh karena itu perlu adanya peningkatan mutu pendidikan agar menghasilkan generasi yang berkualitas.

Matematika merupakan salah satu ilmu yang berkaitan dengan majunya suatu bangsa. Matematika dijadikan salah satu mata pelajaran yang penting untuk diajarkan pada siswa khususnya dalam bidang pendidikan. Hal ini terbukti dengan adanya pelajaran matematika mulai dari Sekolah Dasar (SD) sampai Sekolah Menengah Atas (SMA). Mengingat perlunya ilmu matematika maka pendidikan matematika di sekolah diharapkan dapat memberikan kualitas yang baik agar tujuan dalam pembelajaran dapat tercapai. Namun kenyataannya pelajaran matematika masih belum dikembangkan. Terlihat dalam kegiatan pembelajaran peran guru mempunyai andil yang cukup besar. Pembelajaran hanya berpusat pada guru sedangkan siswa terlihat pasif. Guru memberikan ceramah dan siswa hanya mendengarkan. Selain itu sistem penugasan yang diberikan guru kepada siswa selama ini kebanyakan masih berupa masalah rutin. Sehingga banyak yang beranggapan bahwa matematika merupakan ilmu pasti dan terurut. Siswa jarang diajak menganalisis dalam menyelesaiakan masalah matematika.

Masalah yang terdapat dalam matematika dapat diklasifikasikan menjadi soal rutin dan non rutin. (Masalah, 2013) Soal dikatakan suatu "problem" atau masalah, apabila dalam soal setidaknya memuat 2 hal yakni soal yang menantang pikiran (challenging) dan soal tidak otomatis diketahui proses penyelesaiannya (non routine). Masalah non rutin merupakan masalah yang belum dapat dikerjakan secara langsung, namun mengajarkan siswa menalar serta menganalisis untuk dapat menyelesaikan masalah (Utari, Dwy, Arista, \& Fitri, 2016). Masalah yang mengembangkan kemampuan berpikir kritis adalah masalah non rutin. Menggunakan soal non rutin dapat meningkatkan dalam penalaran logika (Suandito, Kurikulum, \& Satuan, 2009).

Berpikir kritis adalah memahami suatu permasalahan yang ada, mempertahankan pendapat dilihat dari sudut pandang yang berbeda, tidak begitu saja meyakini penjelasan yang datang dari luar sebagaimana diungkapkan oleh (Desmita, 2014). Berpikir kritis merupakan salah satu komponen penting untuk siswa dalam pendidikan matematika. Mengingat pentingnya berpikir kritis maka hendaknya berpikir kritis dikembangkan pada pelajaran matematika. Berdasarkan hasil penelitian (Jumaisyaroh, Napitupulu, \& Hasratuddin, 2015) menunjukkan bahwa kemampuan berpikir kritis matematika siswa Sekolah Menengah Pertama (SMP) masih rendah. Hal ini dibuktikan dengan dibagikan tes kemampuan berpikir kritis matematis dari 30 siswa hanya 2 siswa yang dapat menyelesaikan soal dengan benar.

Proses berpikir kritis setiap individu tentunya berbeda. Perbedaan tersebut dapat terlihat berdasarkan gender. Dalam hal prestasi akademik anak perempuan lebih unggul daripada anak laki-laki. Namun pada mata pelajaran matematika prestasi laki-laki lebih baik daripada perempuan (Ambarawati, 2014). Hal ini dikarenakan laki-laki memiliki kemampuan di bidang numerik dan logika lebih kuat sedangkan perempuan memiliki kemampuan di bidang bahasa, estetika dan sosial.

Semenjak dini seseorang dilatih berpikir secara kritis sebab dengan berpikir kritis akan dapat membantu dalam mengambil sebuah keputusan yang dilakukan dengan logis apabila timbul suatu masalah. Dengan menggunakan konsep berpikir kritis dalam 
matematika secara tepat dapat mengarahkan siswa dalam berpikir serta mempermudah siswa untuk memecahkan masalah matematika.

Seseorang seringkali menemukan suatu permasalahan di dalam kehidupannya dan dituntut untuk dapat memecahkan permasalahan tersebut. Dalam memecahkan suatu masalah biasanya diperlukan berpikir tingkat tinggi. (Polya, 1945) mengelompokkan empat langkah dalam pemecahan masalah, yaitu (1) memahami masalah (understand the problem), (2) membuat rancangan penyelesaian (devise a plan), (3) menyelesaikan masalah (carry out the plan), (4) memeriksa kembali (look back).

Berdasarkan hasil observasi diperoleh informasi dari guru mata pelajaran matematika bahwa siswa kelas 8 SMP Negeri 2 Kauman, Ponorogo masih kesulitan untuk memecahkan masalah matematika yang membutuhkan pemikiran kritis. Oleh karena itu penulis tertarik untuk melakukan penelitian tentang "Profil Kemampuan Berpikir Kritis Siswa SMP dalam Memecahkan Masalah Matematika dengan Informasi yang Kontradiksi Berdasarkan Gender".

\section{METODE PENELITIAN}

Jenis Penelitian

Jenis penelitian yang digunakan dalam penelitian ini adalah penelitian deskriptif kualitatif. Karena penelitian mengarah pada pendiskripsian kondisi sesungguhnya di lapangan yang kemudian diuraikan dalam teks.

Waktu dan Tempat Penelitian

Penelitian ini dilaksanakan di Sekolah Menengah Pertama Negeri 2 Kauman, kabupaten Ponorogo. Pelaksanaan penelitian dilakukan pada tahun ajaran 2017/2018 pada bulan Mei 2018 sampai Juni 2018.

Subjek Penelitian

Subyek yang diambil dalam penelitian ini adalah siswa kelas VIII A SMP Negeri 2 Kauman, kabupaten Ponorogo. Peneliti mengambil subyek sebanyak 2 siswa, yang terdiri dari siswa laki-laki dan siswa perempuan.

Instrumen

Dalam penelitian ini instrumen yang digunakan oleh peneliti yaitu soal tes dan pedoman wawancara. Terdapat 2 butir soal uraian yang diberikan kepada subyek. Setelah subyek diberikan soal tes, kemudian diwawancara mengenai proses yang dilakukan saat menyelesaikan soal.

Teknik Pengumpulan Data

Teknik pengumpulan data yang digunakan dalam penelitian ini adalah sebagai berikut:

1. Tes

Dalam penelitian ini tes disusun sendiri oleh peneliti. Sebelum diujikan peneliti mengkonsultasikan kepada dosen pembimbing terlebih dahulu kemudian divalidasi oleh guru. Tes yang diberikan kepada subjek yaitu berupa soal uraian. Sebab lebih mudah mengetahui kemampuan berpikir kritis melalui soal uraian. 
2. Wawancara

Pedoman wawancara dibuat oleh peneliti sendiri yang sudah direvisi oleh validator dan dikonsultasikan dengan dosen pembimbing. Wawancara dilakukan setelah siswa menyelesaikan tes yang telah dibagikan sebelumnya.

3. Dokumentasi

Dalam penelitian ini menggunakan metode dokumentasi yang berupa gambar yaitu melalui foto. Jika dibandingkan dengan metode yang lainnya, metode ini tidak begitu rumit.

Teknik Keabsahan Data

Berdasarkan berbagai jenis triangulasi, peneliti menggunakan triangulasi waktu.

Penelitian dilakukan pada waktu yang berbeda untuk mengecek kredibilitas data.

Teknik Analisis Data

Dalam penelitian ini komponen yang digunakan dalam analisis data adalah sebagai berikut:

1. Reduksi Data

2. Penyajian Data

3. Penarikan Kesimpulan

\section{HASIL DAN PEMBAHASAN}

Berdasarkan hasil validasi instrumen yang terdiri dari tes dan pedoman wawancara yang dinyatakan valid oleh validator. Kemudian peneliti melakukan penelitian pada siswa kelas VIII A. Instrumen tes diberikan kepada siswa kelas VIII A untuk memperoleh data mengenai kemampuan berpikir kritis siswa. Setelah siswa selesai mengerjakan selanjutnya dipilih 2 subjek untuk dilakukan wawancara. Subjek terdiri dari laki-laki dan perempuan. Pada waktu yang berbeda subjek diberikan tes dan dilakukan wawancara kembali. Data hasil tes dan wawancara dikumpulkan kemudian dianalisis dan dilakukan triangulasi. Peneliti menggunakan triangulasi waktu pada penelitian ini. Kemampuan siswa dalam memecahkan masalah dengan informasi yang kontradiksi dapat dilihat sebagai berikut.

1. Siswa Laki-laki

Dalam memecahkan masalah matematika dengan informasi yang kontradiksi pada pokok bahasan kubus siswa laki-laki mempunyai kemampuan berpikir kritis. Pada tahap interpretasi subjek 1 melakukan aktivitas membaca soal namun tidak menuliskan apa yang diketahui maupun apa yang ditanyakan pada soal. Subjek 1 langsung pada tahap yang berikutnya yaitu tahap analisis. Pada tahap analisis subjek 1 dapat memahami konsep yang dimaksud pada soal dengan informasi yang kontradiksi. Sebelum menyelesaikan masalah subjek 1 merencakan strategi yang akan digunakan saat menyelesaikan soal. Kubus memiliki sisi yang sama panjang. Pada soal terdapat satu sisi yang panjangnya berbeda. Sehingga subjek 1 menyamakan sisi kubus terlebih dahulu. Pada tahap evaluasi subjek 1 menyelesaikan masalah dengan informasi yang kontradiksi dengan menggunakan strategi yang tepat. Soal diselesaikan sesuai dengan rumus yang sesuai dengan pertanyaan yaitu luas permukaan kubus dan volume kubus. Subjek 1 menjelaskan bahwa tidak ada cara lain yang dapat digunakan untuk menyelesaikan soal. Pada tahap inferensi subjek 1 hanya memeriksa kembali langkahlangkah dalam menyelesaikan soal. Subjek 1 tidak membuat kesimpulan. Namun saat 
diwawancara subjek 1 dapat membuat kesimpulan berdasarkan langkah-langkah penyelesaian soal.

Berdasarkan penjabaran tersebut sesuai dengan hasil penelitian yang dilakukakn oleh (Ambarawati, 2014) yang menyatakan bahwa laki-laki dalam fase pengenalan, mereka menemui kesulitan yaitu pertanyaan yang mereka sebutkan kurang lengkap. Selain itu, dalam memikirkan alternatif, mereka hanya mampu menyebutkan satu alternatif pemecahan masalah.

2. Siswa Perempuan

Dalam memecahkan masalah matematika dengan informasi yang kontradiksi pada pokok bahasan kubus siswa perempuan mempunyai kemampuan berpikir kritis. Pada tahap interpretasi subjek 2 melakukan aktivitas membaca soal secara teliti. Selain itu subjek 2 juga menulis apa yang diketahui maupun apa yang ditanyakan pada soal secara rinci. Subjek 2 mengerti bahwa pada soal terdapat satu sisi kubus yang panjangnya kontradiksi dengan sisi yang lain. Pada tahap analisis subjek 2 memahami konsep pada soal dengan informasi yang kontradiksi. Subjek 2 merencanakan strategi sebelum mengerjakan soal dengan informasi yang kontradiksi. Sisi pada kubus harus sama panjangnya. Pada soal yang telah dibagikan peneliti terdapat sisi kubus yang panjangnya berbeda dengan sisi yang lain. Oleh karena itu sebelum menyelesaikan soal subjek 2 menyamakan sisi yang ada pada kubus terlbih dahulu. Pada tahap evaluasi subjek 2 menggunakan strategi yang tepat dalam menyelesaikan masalah dengan informasi yang kontradiksi. Subjek 2 menentukan rumus yang sesuai dengan soal. Subjek 2 menggunakan rumus luas permukaan kubus dan volume kubus dengan tepat. Subjek 2 mengatakan bahwa tidak ada cara lain untuk menyelesaikan soal dengan informasi yang kontradiksi. Pada tahap inferensi subjek 2 memeriksa kembali langkahlangkah dalam menyelesaikan soal. Setelah memeriksa kembali subjek 2 membuat kesimpulan. Kesimpulan dibuat berdasarkan langkah-langkah subjek 2 dalam menyelesaikan soal dengan informasi yang kontradiksi.

Berdasarkan penjabaran tersebut sesuai dengan hasil penelitian yang dilakukakn oleh (Cahyono, 2017) yang menyatakan bahwa perempuan lebih baik dari laki-laki dalam hal keterampilan berpikir kritis dan terdapat perbedaan dalam prosesnya.

\section{KESIMPULAN}

Berdasarkan hasil penelitian yang dilakukan peneliti menunjukkan bahwa siswa laki-laki dan perempuan memiliki kemampuan berpikir kritis dalam memecahkan masalah dengan informasi yang kontradiksi. Siswa laki-laki mampu menerapkan tahap analisis dan tahap evaluasi. Hasil tes tulis pada tahap interpretasi subjek tidak menuliskan yang diketahui maupun yang ditanyakan pada soal. Sedangkan tahap inferensi subjek tidak menuliskan kesimpulan dari penyelesaian soal. Sedangkan siswa perempuan mampu menerapkan tahap interpretasi, tahap analisis, tahap evaluasi dan tahap inferensi.

\section{DAFTAR PUSTAKA}


Ambarawati, M. (2014). Profil Proses Berpikir Kritis Siswa Kelas Viii Smp Negeri 3 Surakarta Dalam Memecahkan Masalah Pokok Bahasan Sistem Persamaan Linear Dua Variabel ( Spldv ) Ditinjau dari Kecerdasan Majemuk dan Gender. Jurnal Elektronik Pembelajaran Matematika, 2(9), 984-994.

Cahyono, B. (2017). Analisis Ketrampilan Berfikir Kritis Dalam Memecahkan Masalah Ditinjau Perbedaan Gender, 8(1), 50-64.

Desmita, D. (2014). Psikologi Perkembangan Peserta Didik. Bandung: PT Remaja Rosdakarya.

Jumaisyaroh, T., Napitupulu, E. E., \& Hasratuddin. (2015). Peningkatan Kemampuan Berpikir Kritis Matematis dan Kemandirian Belajar Siswa SMP Melalui Pembelajaran Berbasis Masalah. AdMathEdu, 5(1), 87-106.

Masalah, B. (2013). Penelitian ini bertujuan untuk mengetahui: ( 1 ) peningkatan kemampuan berpikir kritis matematis siswa setelah pembelajaran dengan menggunakan pembelajaran berbasis masalah dan pembelajaran konvensional , (2) Perbedaan peningkatan kemampuan berpikir kritis matematis antara siswa yang diajar dengan menggunakan pembelajaran berbasis masalah dan siswa yang diajar dengan menggunakan pembelajaran konvensional . Berdasarkan hasil analisis data diperoleh kesimpulan . ( 1 ) Peningkatan kemampuan berpikir kritis matematis siswa yang menggunakan pembelajaran berbasis masalah adalah sebesar 0,80 tergolong klasifikasi tinggi, dimana 90,62\% siswa memperoleh peningkaran lebih dari 0, 70 . ( 2 ) Peningkatan kemampuan berpikir kritis matematis siswa yang menggunakan pembelajaran konvensional adalah sebesar 0,66 tergolong klasifikasi sedang, dimana $72,73 \%$ siswa memperoleh peningka tan dengan menggunakan pembelajaran berbasis masalah lebih baik secara signifikan peningkatannya dari kemampuan berpikir kritis matematis siswa yang diajar dengan menggunakan pembelajaran konvensional ., $1(1), 61-76$.

Polya, G. (1945). How to Solve It. The Mathematical Gazette. https://doi.org/10.2307/3609122

Suandito, B., Kurikulum, D., \& Satuan, T. (2009). Pengembangan Soal Matematika Non Rutin Di Sma Xaverius 4 Palembang. Jurnal Pendidikan Matematika, 3(2), 1-13. Retrieved from http://eprints.unsri.ac.id/819/1/1_Billyl_1-13.pdf

Utari, T., Dwy, E., Arista, W., \& Fitri, A. (2016). Masalah Non Rutin dalam Buku Ajar Matematika untuk Meningkatkan Kemampuan Berpikir Kreatif, 541-548. 